\title{
Front Matter: Volume 8270
}

, "Front Matter: Volume 8270," Proc. SPIE 8270, High Contrast Metastructures, 827001 (21 March 2012); doi: 10.1117/12.931593 


\section{PROCEEDINGS OF SPIE}

\section{High Contrast Metastructures}

Connie J. Chang-Hasnain

Fumio Koyama

Alan Eli Willner

Weimin Zhou

Editors

22-25 January 2012

San Francisco, California, United States

Sponsored and Published by

SPIE 
The papers included in this volume were part of the technical conference cited on the cover and title page. Papers were selected and subject to review by the editors and conference program committee. Some conference presentations may not be available for publication. The papers published in these proceedings reflect the work and thoughts of the authors and are published herein as submitted. The publisher is not responsible for the validity of the information or for any outcomes resulting from reliance thereon.

Please use the following format to cite material from this book:

Author(s), "Title of Paper," in High Contrast Metastructures, edited by Connie J. Chang-Hasnain, Fumio Koyama, Alan Eli Willner, Weimin Zhou, Proceedings of SPIE Vol. 8270 (SPIE, Bellingham, WA, 2012) Article CID Number.

ISSN 0277-786X

ISBN 9780819489135

Published by

SPIE

P.O. Box 10, Bellingham, Washington 98227-0010 USA

Telephone +1 3606763290 (Pacific Time) · Fax +1 3606471445

SPIE.org

Copyright (C) 2012, Society of Photo-Optical Instrumentation Engineers

Copying of material in this book for internal or personal use, or for the internal or personal use of specific clients, beyond the fair use provisions granted by the U.S. Copyright Law is authorized by SPIE subject to payment of copying fees. The Transactional Reporting Service base fee for this volume is $\$ 18.00$ per article (or portion thereof), which should be paid directly to the Copyright Clearance Center (CCC), 222 Rosewood Drive, Danvers, MA 01923. Payment may also be made electronically through CCC Online at copyright.com. Other copying for republication, resale, advertising or promotion, or any form of systematic or multiple reproduction of any material in this book is prohibited except with permission in writing from the publisher. The CCC fee code is 0277-786X/12/\$18.00.

Printed in the United States of America.

Publication of record for individual papers is online in the SPIE Digital Library.

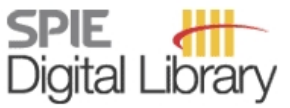

SPIEDigitalLibrary.org

Paper Numbering: Proceedings of SPIE follow an e-First publication model, with papers published first online and then in print and on CD-ROM. Papers are published as they are submitted and meet publication criteria. A unique, consistent, permanent citation identifier (CID) number is assigned to each article at the time of the first publication. Utilization of CIDs allows articles to be fully citable as soon as they are published online, and connects the same identifier to all online, print, and electronic versions of the publication. SPIE uses a six-digit CID article numbering system in which:

- The first four digits correspond to the SPIE volume number.

- The last two digits indicate publication order within the volume using a Base 36 numbering system employing both numerals and letters. These two-number sets start with $00,01,02,03,04$, $05,06,07,08,09,0 A, 0 B \ldots 0 Z$, followed by 10-1Z, 20-2Z, etc.

The CID number appears on each page of the manuscript. The complete citation is used on the first page, and an abbreviated version on subsequent pages. Numbers in the index correspond to the last two digits of the six-digit CID number. 


\title{
Contents
}

\author{
vii Conference Committee \\ ix Introduction \\ xi Spinoptics: Spin degeneracy removal in nanostructures (Plenary Paper) [8269-100] \\ V. Kleiner, N. Shitrit, E. Hasman, Technion-Israel Institute of Technology (Israel)
}

\section{SESSION 1 HARNESSING LIGHT}

827003 Surface addressable photonic crystal membrane resonators: generic enablers for 3D harnessing of light (Invited Paper) [8270-02]

P. Viktorovitch, Institut des Nanotechnologies de Lyon, CNRS, Univ. de Lyon (France);

C. Sciancalepore, Institut des Nanotechnologies de Lyon, CNRS, Univ. de Lyon (France) and CEA-LETI-Minatec(France); T. Benyattou, Institut des Nanotechnologies de Lyon, CNRS, Univ. de Lyon (France); B. Ben Bakir, CEA-LETI-Minatec (France); X. Letartre, Institut des

Nanotechnologies de Lyon, CNRS, Univ. de Lyon (France)

\section{SESSION 2 NOVEL FILTERS}

827005 High contrast grating for spatial mode filtering and mode control of VCSELs (Invited Paper) [8270-04]

F. Koyama, Tokyo Institute of Technology (Japan)

$827007 \quad$ Novel direction selective filter elements based on high-contrast gratings [8270-06] S. Steiner, S. Kroker, T. Käsebier, Institute of Applied Physics, Abbe Ctr. of Photonics, Friedrich-Schiller-Univ. Jena (Germany); F. Fuchs, Fraunhofer Institute of Applied Optics and Precision Engineering (Germany); E.-B. Kley, Institute of Applied Physics, Abbe Ctr. of Photonics, Friedrich-Schiller-Univ. Jena (Germany); A. Tünnermann, Institute of Applied Physics, Abbe Ctr. of Photonics, Friedrich-Schiller-Univ. Jena (Germany) and Fraunhofer Institute of Applied Optics and Precision Engineering (Germany)

827008 Fabrication and characterization of $\mathrm{Si} \mathrm{SiO}_{2}$ high contrast grating using nanoimprint lithography [8270-07]

Y. Hashizume, Y. Miyake, A. Matsutani, Tokyo Institute of Technology (Japan); H. Ohtsuki, SAMCO, Inc. (Japan); F. Koyama, Tokyo Institute of Technology (Japan)

\section{SESSION $3 \quad$ SLOW LIGHT}

827009 Slow-light high contrast metastructure hollow-core waveguides (Invited Paper) [8270-08] W. Zhou, G. Dang, M. Taysing-Lara, U.S. Army Research Lab. (United States); V. Karagodsky, T. Sun, C. Chang-Hasnain, Univ. of California, Berkeley (United States) 
$82700 \mathrm{~A} \quad$ Low-loss slow light inside high contrast grating waveguide [8270-09]

T. Sun, W. Yang, V. Karagodsky, Univ. of California, Berkeley (United States); W. Zhou, U.S. Army Research Lab. (United States); C. Chang-Hasnain, Univ. of California, Berkeley (United States)

8270 OB Disorder model of photonic-crystal waveguides: fast to slow light transition (Invited Paper) [8270-10]

S. Mazoyer, J. P. Hugonin, P. Lalanne, Lab. Charles Fabry (France); D. M. Beggs, L. O'Faolain,

T. F. Krauss, Univ. of St. Andrews (United Kingdom)

\section{SESSION 4 REFLECTORS AND RESONATORS}

8270 OD VCSELs and silicon light sources exploiting SOI grating mirrors (Invited Paper) [8270-12] I.-S. Chung, J. Mørk, Technical Univ. of Denmark (Denmark)

8270 OE Wave-front-engineered grating mirrors for VCSELs [8270-13]

L. Carletti, R. Malureanu, J. Mørk, I.-S. Chung, Technical Univ. of Denmark (Denmark)

8270 OF High frequency binary amorphous silicon grating working as wire grid polarizer for UV applications [8270-14]

T. Weber, T. Käsebier, S. Kroker, E.-B. Kley, Institute of Applied Physics, Abbe Ctr. of Photonics, Friedrich-Schiller-Univ. Jena (Germany); A. Tünnermann, Institute of Applied Physics, Abbe Ctr. of Photonics, Friedrich-Schiller-Univ. Jena (Germany) and Fraunhofer Institute of Applied Optics and Precision Engineering (Germany)

\section{SESSION 5 HOLLOW CORE WAVEGUIDE}

$8270 \mathrm{OH} \quad$ Optical phased array for far field beam steering with varied HCG (Invited Paper) [8270-16]

W. Hu, Peking Univ. (China); C. Chang-Hasnain, Univ. of California, Berkeley (United States)

8270 Ol Low-loss hollow-core waveguide using high-contrast sub-wavelength grating [8270-17]

J. Ferrara, W. Yang, A. Yeh, K. Grutter, C. Chase, V. Karagodsky, D. Parekh, Univ. of California, Berkeley (United States); Y. Yue, A. E. Willner, The Univ. of Southern California

(United States); M. C. Wu, C. J. Chang-Hasnain, Univ. of California, Berkeley (United States)

\section{SESSION $6 \quad$ NOVEL FUNCTIONS}

$8270 \mathrm{OL} \quad$ Novel high efficiency vertical to in-plane optical coupler [8270-20]

L. Zhu, V. Karagodsky, C. Chang-Hasnain, Univ. of California, Berkeley (United States)

$82700 \mathrm{M}$ Design of second order grating couplers to detect the angle and polarization of the laser beam [8270-21]

T. K. Saha, M. Lu, D. Zhao, The Univ. of Texas at Arlington (United States); Z. Ma, Univ. of Wisconsin-Madison (United States); W. Zhou, The Univ. of Texas at Arlington (United States) 
$8270 \mathrm{ON}$ Optical phase shifting based on high contrast grating waveguide [8270-22]

Y. Li, Peking Univ. (China); T. Sun, Univ. of California, Berkeley (United States); T. Chen, H. Jiang, W. Hu, Peking Univ. (China); C. Chang-Hasnain, Univ. of California, Berkeley (United States)

8270 OP Diffractive optical elements based on subwavelength high-contrast gratings [8270-24]

S. Kroker, T. Käsebier, T. Weber, S. Steiner, Institute of Applied Physics, Abbe Ctr. of Photonics, Friedrich-Schiller-Univ. Jena (Germany); F. Fuchs, Fraunhofer Institute of Applied Optics and Precision Engineering (Germany); E.-B. Kley, Institute of Applied Physics, Abbe Ctr. of Photonics, Friedrich-Schiller-Univ. Jena (Germany); A. Tünnermann, Institute of Applied Physics, Abbe Ctr. of Photonics, Friedrich-Schiller-Univ. Jena (Germany) and Fraunhofer Institute of Applied Optics and Precision Engineering (Germany)

$82700 Q \quad$ High-contrast grating based planar light concentrators (Invited Paper) [8270-29]

B. Pesala, CSIR-Central Electronics Engineering Research Institute (India)

\section{SESSION 8 METASTRUCTURES}

8270 OR Acrobatics for thermal emission using metastructures (Invited Paper) [8270-25] V. Kleiner, N. Dahan, K. Frischwasser, E. Hasman, Technion-Israel Institute of Technology (Israel)

8270 OS Low-loss silica on silicon integrated waveguides [8270-26]

A. J. Maker, A. M. Armani, The Univ. of Southern California (United States)

8270 ОT Suspended silica beam splitters on silicon with large core-clad index deference [8270-27] X. Zhang, A. M. Armani, The Univ. of Southern California (United States)

\section{POSTER SESSION}

$8270 \mathrm{OU}$ Tuning the reflectivity of high-contrast gratings based on silicon and silica by means of wet etching with hydrofluoric acid [8270-28]

T. Jacobitz, S. Kroker, T. Käsebier, E.-B. Kley, Institute of Applied Physics, Abbe Ctr. of Photonics, Friedrich-Schiller-Univ. Jena (Germany); A. Tünnermann, Institute of Applied Physics, Abbe Ctr. of Photonics, Friedrich-Schiller-Univ. Jena (Germany) and Fraunhofer Institute of Applied Optics and Precision Engineering (Germany)

Author Index 
Downloaded From: https://www.spiedigitallibrary.org/conference-proceedings-of-spie on 26 Apr 2023

Terms of Use: https://www.spiedigitallibrary.org/terms-of-use 


\title{
Conference Committee
}

\author{
Symposium Chair
}

Klaus P. Streubel, OSRAM GmbH (Germany)

Symposium Cochairs

David L. Andrews, University of East Anglia Norwich (United Kingdom) Liang-Chy Chien, Kent State University (United States)

Program Track Chair

Ali Adibi, Georgia Institute of Technology (United States)

\section{Conference Chairs}

Connie J. Chang-Hasnain, University of California, Berkeley (United States)

Fumio Koyama, Tokyo Institute of Technology (Japan)

Alan Eli Willner, The University of Southern California (United States)

Weimin Zhou, U.S. Army Research Laboratory (United States)

\section{Program Committee}

Markus-Christian Amann, Walter Schottky Institute (Germany)

David Fattal, Hewlett-Packard Laboratories (United States)

Weiwei Hu, Peking University (China)

Ernst-Bernhard Kley, Friedrich-Schiller-Universität Jena (Germany)

Philippe Lalanne, L aboratoire Charles Fabry (France)

Rainer F. Mahrt, IBM Zürich Research Laboratory (Switzerland)

Jesper Mørk, Technical University of Denmark (Denmark)

Pierre Viktorovitch, Ecole Centrale de Lyon (France)

Ming C. Wu, University of California, Berkeley (United States)

Session Chairs

$1 \quad$ Harnessing Light

Weimin Zhou, U.S. Army Research Laboratory (United States)

2 Novel Filters

Weimin Zhou, U.S. Army Research Laboratory (United States)

3 Slow Light

Ming C. Wu, University of California, Berkeley (United States) 
$4 \quad$ Reflectors and Resonators

Pierre Viktorovitch, Ecole Centrale de Lyon (France)

5 Hollow Core Waveguide

Fumio Koyama, Tokyo Institute of Technology (Japan)

6 Novel Functions

Ernst-Bernhard Kley, Friedrich-Schiller-Universität Jena (Germany)

7 Optical Phase Engineering

Thilo Stöferle, IBM Zürich Research Laboratory (Switzerland)

8 Metastructures

David Fattal, Hewlett-Packard Laboratories (United States) 


\section{Introduction}

Optical structures that are on the order of optical wavelength have been used to change the optical properties of the structures, similar to the use of nanostructures for quantization of electron wave. Recently, a new class of single planar layer subwavelength metastructures has emerged. The new metastructures are dielectric gratings with a large index contrast that can be designed to exhibit many extraordinary properties. For example, high contrast gratings (HCG) can provide very high reflection over a broad spectral range for light propagating in the direction orthogonal to the periodicity. It can also be designed to be a resonator with an extremely high quality factor and with userfriendly surface-normal coupling. Furthermore, changing the grating dimension individually, an ultra-thin lens or focusing reflector with high focusing power can be obtained.

This conference is the first one devoted to this theme. The presentations include a wide range of exciting advances, ranging from new physics, theories, to device applications. Various materials and fabrication technologies were used as basic platforms. In these proceedings, the readers will find discussion of novel direction selective filter elements, deep ultraviolet (DUV) polarizer and low noise infraredmirrors. HCG designs to provide spatial mode filtering for mode control of VCSELS and wave-front-engineered mirrors are discussed. Phase engineering using HCG are explored in surface-normal transmission for solar cell concentrator optics and spiral lens applications. Using it at a glancing angle for hollow core waveguide, slow light waveguides are demonstrated. In addition, dynamically tunable allpass filter array for fast optical beam steering is also presented.

During and post conference, we received much positive feedback and encouragement from attendees and presenters. There is a genuine sense of excitement and enthusiasm about this topic, as evinced by the full-house attendance and lively question/answer sessions after each talk. We are grateful to all the attendees for asking so many valuable questions. As always, the primary ingredient for a successful technical conference is the quality of the work presented by the contributors, so we would like to extend a special thanks to all the contributors for the quality of their presentations, and their eagerness to share new information and discuss different points of view. We would like also to express our gratitude to all keynote and invited speakers for presenting exceptional overviews and igniting thought-provoking discussions. We are grateful to the committee members and session chairs, as their support and dedication before 
and during the event had a significant impact on the outcome and success of the meeting.

\section{Connie J. Chang-Hasnain Fumio Koyama \\ Alan Eli Willner Weimin Zhou}

